\title{
On a Prothallus provisionally referred to Psilotum.
}

\author{
BY \\ WILLIAM H. LANG, M.B., D.Sc., \\ Lecturer in Botany at Queen Margaret College, University of Glasgow.
}

\section{With Plate XXXVII.}

$\mathrm{T}^{1 / 2}$ HE only important group of the Pteridophyta in which the sexual generation is unknown is that of the Psilotaceae, comprising the two existing genera Psilotum and Tmesipteris. While travelling in localities in which Psilotum occurred, I spent considerable time in examining the neighbourhood of the plants met with in the hope of finding specimens of the prothallus. The sporophyte was found growing in various situations in a number of localities. In Ceylon it was once or twice seen growing in the soil below coco-nut trees near the coast, and very abundantly on the masses of roots which form the swollen base to the stems of these palms. In the mountain region it was seen growing as an epiphyte, its rhizome spreading through the humus accumulated in the fork of a tree, and occasionally growing on rocks. The observations made in Ceylon were without result; in most cases the start of any isolated portion of rhizome could be best accounted for by an origin from one of the gemmae borne in large numbers on the rhizome. In the localities I visited in the Malay Peninsula ${ }^{1}$ Psilotum was not abundant, but in one of them, Maxwell's Hill in Perak, a number of plants were found growing on the stems of treeferns. The rhizome was embedded among the adventitious roots covering the stem of the tree-fern, while the aerial shoots projected more or less from the surface; they were not flattened, so that the species was presumably $P$. triquetrum. In close association with one of these plants the single prothallus, on the study of which the following description is based, was found. A preliminary account of its external form has already been published $^{2}$.

1 The scientific expenses of my expedition to the Malayan Peninsula were met by a grant of the Royal Society.

2 Proc. Roy. Soc., vol. 1xviii, I90I, p. 405.

[Annals of Botany, Vo1. XVIII. No. LXXII. October, 1904.]

$\mathrm{R} r$ 
The prothallus was almost certainly completely embedded among the adventitious roots, although, since some of the latter had been removed before it was noticed, this was not directly observed. Its general form will be evident from Figs. I and 2, which represent two views of the uninjured prothallus magnified seven times. Its natural size was about one quarter of an inch in length by three-sixteenths of an inch across at the upper end, which was the widest part. As the figures show, it was approximately cylindrical, agreeing in general form and symmetry with the prothalli of some species of Lycopodium. As in these, a lower vegetative region could be distinguished from an upper one, to which the sexual organs were confined. The vegetative region, which formed the larger portion of the prothallus, was of a brown colour and thickly clothed with rhizoids. Below, and somewhat to one side, it narrowed into a conical end, the relation of which to the general body of the prothallus at once suggests a comparison with the primary tubercle, which is more or less clearly distinguishable in most prothalli of Lycopodium. The upper portion of the prothallus consisted of a somewhat depressed central area and a thick overhanging margin, in which numerous antheridia were present. A comparison of Fig. 3, which represents a section through the whole prothallus, with Fig. 4, in which the overhanging margin is better seen, will make the relation of these parts clear without further description. It is sufficient to point out that, as in most types of Lycopodium prothalli, this prothallus is differentiated into a primary tubercle, a vegetative region, and a sexual region. There was clearly no apical growth, and, as will be shown below, the zone intervening between the vegetative and sexual regions must be regarded as the meristematic region. The fact that the sexual organs were confined to the margin of the sexual region indicates that the prothallus was a relatively old one. A comparison with prothalli of various ages of e. g. Lycopodium clavatum $^{1}$ makes the manner in which the existing relation of parts would follow from one in which the whole summit of the prothallus was covered with sexual organs perfectly clear.

There was no trace of the existence of any assimilating lobes such as occur among the sexual organs of Lycopodium cermum. When fresh the upper portion of the prothallus had a faintly green tint, but examination on the spot did not reveal any chlorophyll corpuscles, nor could any be detected on more careful examination later. It is therefore probable that the prothallus was not exposed to light, and was incapable of independent assimilation.

The structure of the several regions of the prothallus must now be described in detail. The most convenient order in which to take them will be the sexual region, the vegetative region with the primary tubercle, and

1 Bruchmann, Ueber die Prothallien und die Keimpflanzen mehrerer europäischer Lycopodien. Gotha, I898. Cf. Taf. 3, Fig. I, with the series of prothalli of various ages on Taf, $\mathbf{~}$. 
the meristematic region. The symbiotic Fungus will be considered along with the vegetative region, in which it occurs.

The general relation of the sexual region to the rest of the prothallus has been described above. It only remains to point out that, as a comparison of the sections in Figs. 3 and 4 indicates, the thick margin was not equally developed all round. The former cut missed the overhanging edge on both sides, while the latter is taken through a place where it was well developed. The hypertrophied appearance of this edge was very striking; it was thrown into folds, and at places tears in its interior showed the strain which the development of the surface bearing the antheridia had caused. The antheridia originated in regular succession, the youngest being next the meristematic region, the position of which is marked with a cross in Fig. 4. From the few developmental stages observed it was clear that the antheridium originates in the same way as that of Lycopodium, the first division separating an outer cell, which forms the wall, from an inner one giving rise to the mass of spermatocytes. The outer wall of the mature antheridium (Figs. 5, 6) is one layer of cells thick, and is nearly level with the surface of the prothallus. Sometimes the antheridium was extended parallel to the surface as in those figured, while in other cases it was elongated at right angles to the surface. There were no hairs (paraphyses) growing from the surface among the sexual organs.

The vegetative region exhibited greater histological differentiation in relation to the presence within it of an endophytic Fungus, the definite distribution of which indicated its symbiotic nature. The central mass of tissue was entirely free from the Fungus, which was confined to a peripheral zone indicated by the shading on the cut surface of the prothallus in Fig. 3 . The mycorhizal zone is continuous over the whole vegetative half of the prothallus (Figs. 3, 4, 8). On approaching the meristematic zone it narrows (Fig. 4), and in this situation the development of its constituent layers could be traced.

The relative position and appearance of these layers will be evident from the diagram in Fig. 8 and the slightly diagrammatic drawing in Fig. 7. The outermost layer $(a)$ consisted of cells free from the Fungus, save for filaments passing across from the bases of the rhizoids and entering the cells of the deeper layers. The rhizoids are simple protrusions of cells of this layer, and most of them contained one or more fungal hyphae; whether these are to be regarded as passing inwards or outwards could not be determined, but the latter interpretation is more probable. Within the peripheral layer comes a zone of three or four layers of cells $(b)$, the more external of which, like the superficial ones, were extended tangentially, while the inner cells have their longer axes at right angles to the surface, but do not form a distinct layer. These cells, each of which had a single healthylooking nucleus in a central position, were filled with fine fungal hyphae, 
which ran concentrically round the cell and almost completely obliterated the cell-cavity. So far as could be seen the hyphae were non-septate: they were very fine, and in well-stained specimens could be seen to contain numerous small nuclei. In a small proportion of the cells of this zone vesicular structures occurred in addition to the hyphae. They were relatively small and thin-walled, but otherwise resembled the vesicles, which are such a striking feature of the layer next to be described (c). This consisted of a single layer of long narrow cells standing at right angles to the surface. Fungal hyphae could in favourable preparations be demonstrated running between the cells in the thickened cell-wall, but the prominent feature of this layer was the presence of numerous oval vesicles, the position and general appearance of which are sufficiently shown in Fig. 7. The vesicles, which were intercellular, bulged out the septa in which they lay, and frequently obliterated the lumen of the cells on one or both sides. In suitable specimens it could be seen that they were borne on hyphae, but whether they were always terminal, as they appeared in all the cases observed, could not be determined. Close to the meristematic region they were thin-walled (Fig. 9, a), but in all the older regions the walls were thick and stained intensely with some dyes, e.g. safranin when used in combination with haematoxylin. The vesicles were filled with cytoplasm, no central vacuole being as a rule present; in most cases numerous small nuclei were evenly distributed through the cytoplasm (Fig. 9). In other cases the nuclei appeared to be aggregated in one or several groups, the rest of the cytoplasm being practically free from them. No signs of any further development was observed in the vesicles within the tissues of the prothallus. Internal to the layer of elongated cells is the parenchymatous tissue $(d)$, which composes the central portion of the vegetative region of the prothallus. This tissue was entirely free from the endophyte, and its cells presented no characters which call for special note.

The arrangement of the various tissues in the conical base of the prothallus must be referred to in order to complete the description of the vegetative region. The diagram in Fig. 8 , which is founded on a section passing through the middle of the projection, will make the matter clear. The region occupied by the Fungus is shaded, and the several layers are indicated by the same letters as in Fig. 7. It will be evident that in the upper portion of the conical projection the arrangement is exactly the same as has been described above. It is only at the extreme tip of the projection, the region which was first developed on germination, that a difference is found. There, as is the rule in the similar prothalli of Lycopodium, the endophytic Fungus inhabits the superficial cells as well as the layers beneath; the inner layers are also less regular here. Strictly speaking it is this tip only, and not the whole of the projection, that is comparable to 
the primary tubercle. The state of things is much the same as in the prothallus of Lycopodium clavatum ${ }^{1}$.

The zone intervening between the vegetative and sexual regions must be regarded as the meristem of the prothallus on account of the succession of antheridia in the tissues above and the gradual differentiation of the mycorhizal tissues below. But little or nothing in the character of the cells of this zone indicated their meristematic nature. Probably, as is the case also in the subterranean prothalli of Lycopodium, this may be placed in relation to the slowness of growth. Whether this is the true explanation or not, it was impossible to arrive at any conclusion as to the succession of divisions in the meristematic cells from the single specimen available for study.

Comparison with other prothalli, such as those of the Lycopodiaceae and Ophioglossaceae, justifies us in regarding the endophytic Fungus, the strictly limited distribution of which has been described above, as mycorhizal. The general differentiation of the tissues of the prothallus, the absence of chlorophyll, and the position in which the prothallus grew, all support the conclusion that it was a total saprophyte dependent in its nutrition upon the co-operation of the endophytic Fungus.

It now remains to inquire to what extent we are justified in ascribing this prothallus to Psilotum. Our knowledge of the characteristics of the gametophyte in the great groups of Vascular Cryptogams is sufficient to enable us at once to limit the inquiry as to the systematic position of this prothallus to the homosporous Lycopodiaceae and the Psilotaceae. The gametophyte is known in a considerable number of species of Lycopodium and in Phylloglossum, and I have previously discussed the several types occurring in the former genus ${ }^{2}$. The subsequent discovery of the prothallus of Phylloglossum ${ }^{3}$, which appears to resemble most closely that of Lycopodium cernum, though without the assimilatory lobes of the latter, confirms the view that this is the primitive type of prothallus in the group. In the paper cited I suggested several lines of adaptation to explain the various types of wholly saprophytic prothallus in the genus. A special type characteristic of the epiphytic forms (L. Phlegmaria, \&c.) can be distinguished from the massive subterranean prothalli of a number of species normally growing in soil rich in humus. This latter type, as Bruchmann's ${ }^{4}$ exhaustive work shows, presents various grades of specialization of the tissue containing the endophytic Fungus.

The prothallus under discussion, with its radial symmetry and its growth referable to a meristematic zone between the vegetative and sexual regions, is obviously constructed on the general plan traceable throughout the known prothalli of Lycopodium. In size and general appearance it

1 Bruchmann, loc. cit.

3 Thomas, Proc. Roy. Soc., vol. lxix, I9or, p. 285.

2 Annals of Botany, vol. xiii, I899, p. 279.

4 Loc. cit. 
approaches most closely to the wholly saprophytic subterranean type, and in the differentiation of its fungus-containing region is practically identical with Lycopodium complanatum ${ }^{1}$. It does not resemble closely any of the prothalli of tropical species hitherto described. Its form and structure would, however, be quite consistent with its belonging to some tropical species of Lycopodium, the life-history of which is at present unknown.

The only other possible position to assign to this prothallus is to regard it as belonging to Psilotum. Since direct evidence is lacking, we can only estimate the probability of this view indirectly. I shall therefore simply state in conclusion the reasons which incline me to provisionally assign this prothallus to Psilotum rather than to some species of Lycopodium. I recognize fully that no decisive weight can be attached to the arguments which follow, and that it must be left to future research to confirm or disprove my view.

In the first place, it appears to me that considerable weight may fairly be attached to the close association of the prothallus with a plant of Psilotum. It was found a few inches from this plant, embedded, as the rhizomes of the latter were, among the roots of the tree-fern. In my short stay in the locality I did not observe any species of Lycopodium growing in the same situation, though of course such may occur. My personal experience of searching for prothalli of Lycopodium would not lead me to expect those of any species to be so common as to be likely to turn up in situations not as a rule occupied by the sporophyte. At least I should regard the chances as being against a single prothallus found close to a plant of Psilotum being one of a species of Lycopodium sown from a distance. I incline to regard it as more probably related to the plant of Psilotum in its immediate neighbourhood, though I should hesitate to express an opinion as to whether it had sprung from a spore of this plant or whether the latter had originated from another prothallus sown at the same date. Our knowledge of the rate of growth alike of Psilotum and of saprophytic prothalli of this type is too imperfect to help us to come to a decision.

In the second place, the prothallus under consideration may, so far as generalizations are possible on the subject, be regarded as belonging to the wholly saprophytic subterranean type, such as that of Lycopodium clavatum or L. complanatum. It is remarkable to find such a prothallus in a situation to which a prothallus of the type of L. Phlegmaria would appear better adapted. But when the range of situation in which the plants of Psilotum are known to occur is taken into consideration this difficulty would admit of a satisfactory explanation. Psilotum is not an obligative epiphyte ; it is known to grow in soil, and it would not be surprising if its gametophyte were of the subterranean type.

On these grounds I am disposed to regard it as probable that this 1 Bruchmann, loc. cit., Taf. 5 . 
prothallus is really that of Psilotum. It will be of interest to see whether this assumption proves correct or not. In the meantime it would be obviously inadvisable to discuss the bearing of the type of prothallus on the question of the affinity of the Psilotaceae, further than to say that if this prothallus is proved to belong to Psilotum, it will lend support to the close association of the latter with the homosporous Lycopodiaceae.

\section{EXPLANATION OF FIGURES IN PLATE XXXVII.}

Illustrating Dr. Lang's paper on a Prothallus provisionally referred to Psilotum.

Fig. I. The prothallus seen from the side. $\times 7$.

Fig. 2. The prothallus seen from the side and from above. $\times 7$.

Fig. 3. The prothallus halved in a plane parallel to but just avoiding the conical projection and viewed from the cut surface. $\times 7$.

Fig. 4. Section through the junction of the vegetative and sexual regions, showing the protuberant edge of tissue bearing the antheridia; the cross indicates the position of the meristematic region. $\times 25$.

Figs. 5, 6. Vertical sections through antheridia. $\times 375$.

Fig. 7. Vertical section through the mycorhizal region, showing the arrangement of the layers of cells inhabited by the fungus. $a$. superficial layer, $b$. layers with intracellular hyphae, $c$. layer of elongated cells with intercellular hyphae and vesicles, $d$. parenchymatous tissue free from fungal hyphae. $\times 200$.

Fig. 8. Diagrammatic section through the base of the prothallus and the primary tubercle, showing the distribution of the fungus. a.b.c.d., as in Fig. 7. $\times 25$.

Fig. 9. Three of the multinucleate vesicles borne on the endophytic fungus. $\times 375$. 


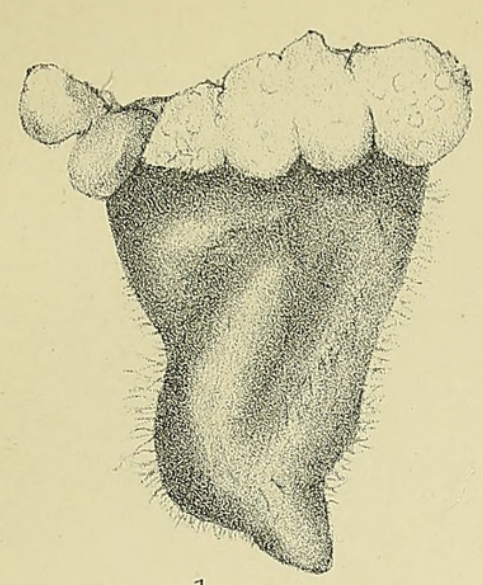

1.
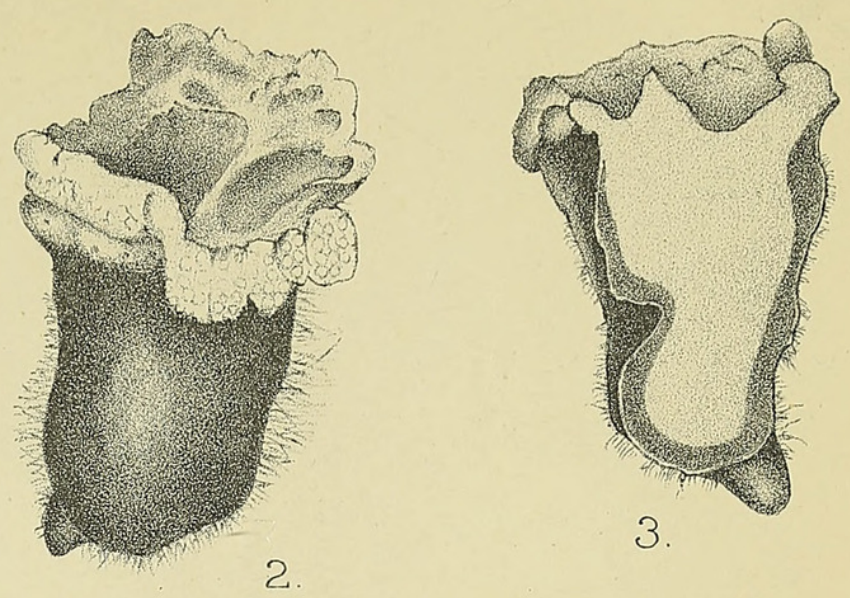

3.
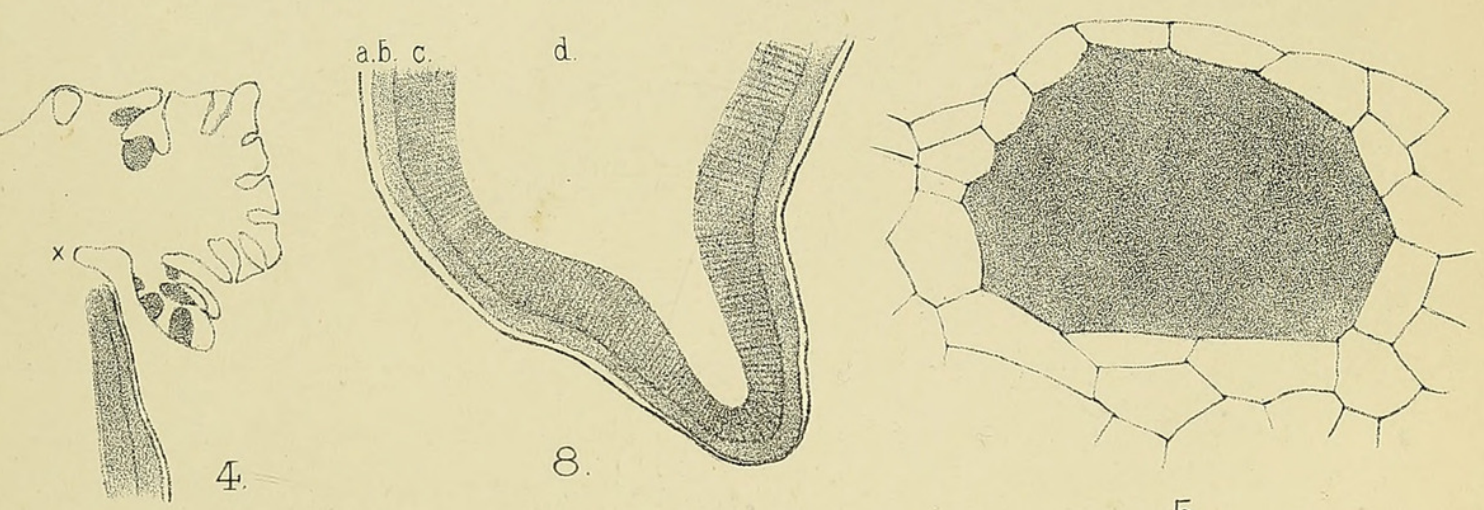

5 .

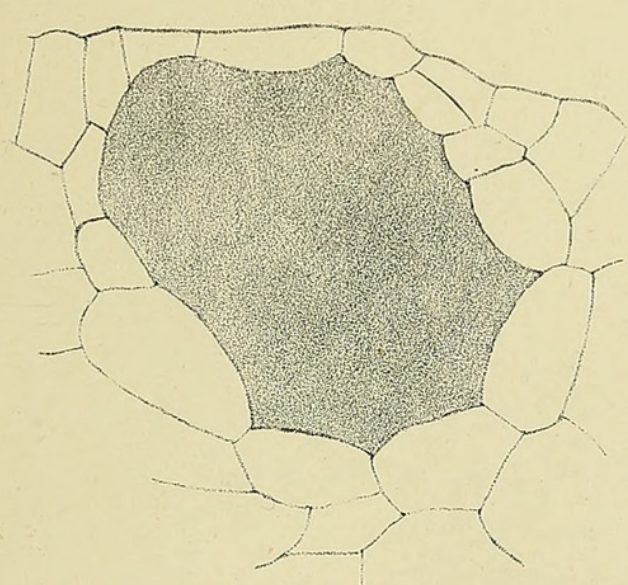

6.
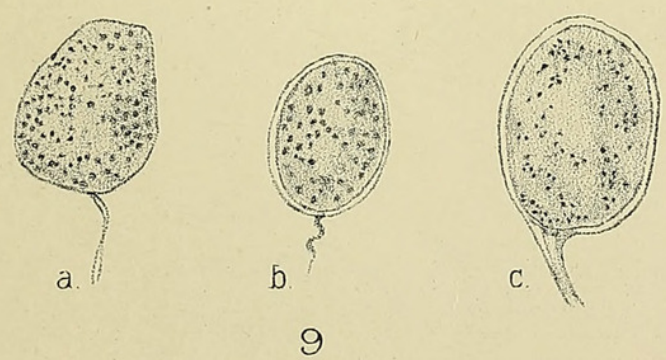

9

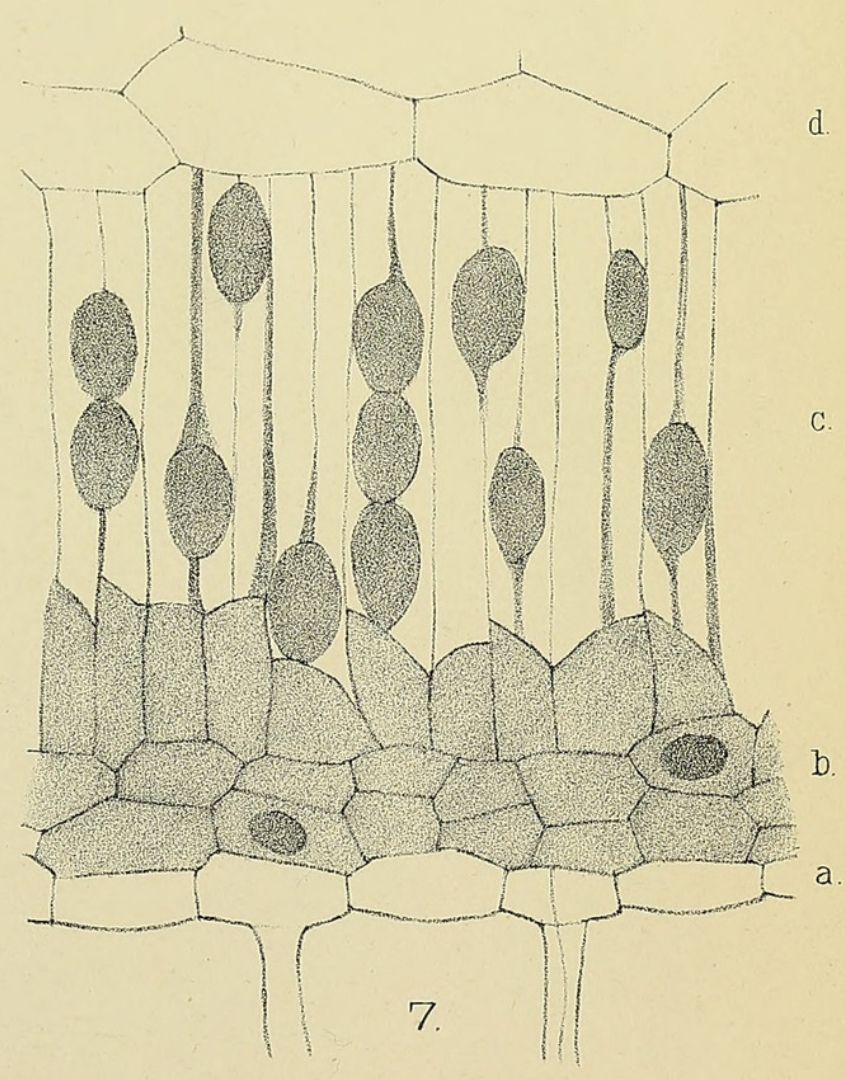




\section{$2 \mathrm{BHL}$ Biodiversity Heritage Library}

Lang, W. H. 1904. "On a prothallus provisionally referred to Psilotum." Annals of botany 18, 571-577. https://doi.org/10.1093/oxfordjournals.aob.a088976.

View This Item Online: https://www.biodiversitylibrary.org/item/234469

DOI: https://doi.org/10.1093/oxfordjournals.aob.a088976

Permalink: https://www.biodiversitylibrary.org/partpdf/318774

\section{Holding Institution}

Smithsonian Libraries

\section{Sponsored by}

Biodiversity Heritage Library

\section{Copyright \& Reuse}

Copyright Status: Not in copyright. The BHL knows of no copyright restrictions on this item.

This document was created from content at the Biodiversity Heritage Library, the world's largest open access digital library for biodiversity literature and archives. Visit BHL at https://www.biodiversitylibrary.org. 